\title{
History, Sovereignty, Capital: Company Colonization in South Australia and New Zealand ${ }^{\dagger}$
}

\author{
Matthew Birchall \\ Jesus College, University of Cambridge, Cambridge, CB5 8BL, UK \\ Corresponding author. E-mail: mb2019@cam.ac.uk
}

\begin{abstract}
This article takes a fresh look at the history of private colonial enterprise in order to show how companies influenced British settlement and emigration to South Australia and New Zealand in the 1830s, thus connecting the settler revolution to global capitalism. Bringing into a single analytical frame the history of company colonization in the antipodes and its Atlantic predecessor, it examines how and why the actors involved in the colonization of South Australia and New Zealand invoked North American precedent to justify their early nineteenth-century colonial ventures. The article shows how the legitimating narratives employed by the colonial reformers performed two key functions. On the one hand, they supplied a historical and discursive tradition that authorized chartered enterprise in the antipodes. On the other hand, they furnished legal arguments that purportedly justified the appropriation of Aboriginal Australian and Māori tribal land. In illuminating how language and time shaped the world-making prophesies of these colonial capitalists, the article aims to extend recent work on corporations in global context.
\end{abstract}

Keywords: company colonization; global capitalism; settler revolution; sovereignty

This article seeks to demonstrate the importance of chartered colonial enterprise to the settler revolution. Characterized by mass emigration to Britain's settler colonies during the long nineteenth century, the settler revolution transformed Chicago and Melbourne, London and New York, drawing all into a vast cultural and political network that straddled the globe. ${ }^{1}$ But while the settler revolution is now well integrated into British imperial history, it remains curiously disconnected from the history of global capitalism. ${ }^{2}$ In the wake of the Napoleonic wars,

\footnotetext{
${ }^{\dagger}$ My thanks to Alison Bashford and Duncan Bell for commenting upon countless drafts of this article. Lisa Ford has been an exemplary (and patient) mentor, for which I am very grateful. In addition, I would like to thank the two anonymous reviewers who engaged so carefully with the article's central arguments, as well as the editors of the Journal of Global History for constructive feedback and consummate professionalism. Finally, I would like to acknowledge the late Eric Richards, eminent historian of British migration. Our conversations at Flinders University were consistently thought-provoking. He was a fine man.

${ }^{1}$ James Belich, Replenishing the Earth: The Settler Revolution and the Rise of the Anglo-World, 1783-1939 (Oxford: Oxford University Press, 2009).

${ }^{2}$ But see the suggestive possibilities opened up in Ben Huf and Glenda Sluga, "New” Histories of (Australian) Capitalism', Australian Historical Studies 50 (2019): 405-17. Philip McMichael showed clearly some time ago that settler capitalism was tightly connected to pastoral expansion, but he had little to say about corporations. See Philip McMichael, Settlers and the Agrarian Question: Foundations of Capitalism in Colonial Australia (Cambridge: Cambridge University Press, 1984). See also Christopher Lloyd, Jacob Metzer, and Richard Sutch, eds., Settler Economies in World History (Leiden: Brill, 2013). Donald Denoon's Settler Capitalism: The Dynamics of Dependent Development in the Southern Hemisphere (New York: Oxford University Press, 1983) concerns itself with the second half of the nineteenth century, limiting its application here.

(C) The Author(s), 2020. Published by Cambridge University Press.. This is an Open Access article, distributed under the terms of the Creative Commons Attribution licence (http://creativecommons.org/licenses/by/4.0/), which permits unrestricted re-use, distribution, and reproduction in any medium, provided the original work is properly cited.
} 
however, a suite of antipodean colonization and agricultural trading companies were established in London, all of which had a profound impact on British imperial policy. Nevertheless, world histories of chartered colonial enterprise have tended to overlook this so-called moment of 'colonial reform', temporally as much as geographically. The historiography of what I call company colonization, defined broadly as corporate and commercial colonization, thus jumps from the early modern to the 'Scramble for Africa', from the world of the Virginia Company and the East India Company to that of the Royal Niger Company and the British South Africa Company. ${ }^{3}$

At the same time, historians of South Australia and New Zealand have often taken for granted the role played by London-based companies, rarely questioning why the company model exerted so much influence over their respective early histories. ${ }^{4}$ This article takes a fresh look at antipodean land settlement in an attempt to map a new history of chartered colonial enterprise, one that is as sensitive to rhetoric as it is to ledgers documenting profit and loss. ${ }^{5}$ It argues that company colonization was as much an act of the imagination as it was the product of prudent capital investment. ${ }^{6}$

Prising open what I call the inner lives of colonial corporations, the article explores the work done by history and historical narrative in legitimating company colonization in the extra-European world. The re-enactment of tradition was central to how these company men made sense of their imperial endeavours, what Nomi Claire Lazar in another register has nominated 'temporal framing. ${ }^{7}$ Insofar as I am interested in recapturing the lost discursive world of these companies, I am concerned with the corporate conscription of time and temporality. ${ }^{8}$ To what extent did impressions of the past shape visions of the colonial future? Did history itself serve as the handmaiden of settler capitalism?

The recent global turn in historiography has been accompanied by a revivified interest in Britain's settler colonies, much of it focused on demonstrating how the settler world wielded an outsize influence over the British imperial imagination during the nineteenth century. ${ }^{9}$

\footnotetext{
${ }^{3} \mathrm{~A}$ recent example that analyses early modern corporations in global context is William A. Pettigrew and David Veevers, eds., The Corporation as a Protagonist in Global History, c. 1550-1750 (Leiden: Brill, 2018). See also Edward Cavanagh, 'Corporations and Business Associations from the Commercial Revolution to the Age of Discovery: Trade, Jurisdiction and the State, 1200-1600', History Compass 14 (2016): 493-510; J. C. Sharman and Andrew Phillips, Outsourcing Empire: How Company-States Shaped the Modern World (Princeton: Princeton University Press, forthcoming); Steven Press, Rogue Empires: Contracts and Conmen in Europe's Scramble for Africa (Cambridge, MA: Harvard University Press, 2017). For classic studies of colonial reform, see Bernard Semmel, The Rise of Free Trade Imperialism: Classical Political Economy, the Empire of Free Trade and Imperialism 1750-1850 (Cambridge: Cambridge University Press, 1970); Donald Winch, Classical Political Economy and Colonies (Cambridge, MA: Harvard University Press, 1965); R. C. Mills, The Colonization of Australia (1829-42): The Wakefield Experiment in Empire Building (London: Sidgwick and Jackson, 1915).

${ }^{4}$ On systematic colonization and South Australia, see Douglas Pike, Paradise of Dissent: South Australia, 1829-1857 (Longman: London, 1957); Hannah Robert, Paved with Good Intentions: Terra Nullius, Aboriginal Land Rights and Settler-Colonial Law (Canberra: Halstead, 2016); Mills, Colonization of Australia. For the New Zealand Company, see Damon Salesa, Racial Crossings: Race, Intermarriage, and the Victorian British Empire (Oxford: Oxford University Press, 2012), 28-53; J. S. Marais, The Colonisation of New Zealand (London: Dawsons, 1968); Patricia Burns, Fatal Success: A History of the New Zealand Company (Auckland: Heinemann, 1989).

${ }^{5}$ I draw here on the work of David Hancock, whose study of London merchants who traded with America in the eighteenth century deftly weaves together a social and business history of imperial commerce. See David Hancock, Citizens of the World: London Merchants and the Integration of the British Atlantic Community, 1735-1785 (New York: Cambridge University Press, 1995).

${ }^{6}$ The article in this sense speaks to recent analyses of global capitalism that emphasize the salience of cultural factors. See Kenneth Lipartito, 'Reassembling the Economic: New Departures in Historical Materialism', American Historical Review 121 (2016): 101-39.

${ }^{7}$ Nomi Claire Lazar, Out of Joint: Power, Crisis, and the Rhetoric of Time (New Haven: Yale University Press, 2019).

${ }^{8}$ Vanessa Ogle, 'Time, Temporality and the History of Capitalism', Past \& Present 243 (2019): 312-27; William H. Sewell Jr, 'The Temporalities of Capitalism', Socio-Economic Review (2008): 517-37.

${ }^{9}$ See, for example, Annie E. Coombs, ed., Rethinking Settler Colonialism: History and Memory in Australia, Canada, Aotearoa New Zealand and South Africa (Manchester: Manchester University Press, 2006); Fiona Bateman and Lionel Pilkington, Studies in Settler Colonialism: Politics, Identity and Culture (Basingstoke: Palgrave, 2011). For a conceptual analysis of settler colonialism, see Lorenzo Veracini, Settler Colonialism: A Theoretical Overview (Basingstoke: Palgrave, 2010). Much of this work has been influenced by the late Patrick Wolfe: see Patrick Wolfe, 'Settler Colonialism and the Elimination of the Native', Journal of Genocide Research 8 (2006): 387-409.
} 
After all, it was in the settler colonies, as Duncan Bell reminds us, that 'many liberals found the concrete place of their dreams'. ${ }^{10}$ I seek to complement this recent wave of scholarship, affirming the general significance of settler colonialism to both British imperial and world history in the early nineteenth century, while at the same time opening up new terrain by foregrounding the conceptual connection between colonial reform and global capitalism. In thus rethinking colonial reform, I contend that a conceptual trinity powered the company colonization of South Australia and New Zealand: history, sovereignty, and capital.

An interrogation of the colonial reform movement also puts settler colonial history back into productive dialogue with Atlantic history, robust yet fairly distinct historiographical traditions. ${ }^{11}$ The pivotal role that America plays in this re-reading of the colonial reform movement prompts us to reconsider how history and historical narrative informed practical plans to colonize South Australia and New Zealand. Colonial North America was routinely mustered by the colonial reformers to justify their ventures, a powerful symbol of chartered colonial success that was strategically invoked in correspondence with the Colonial Office. If the Virginia Company and the Trustees of Georgia had settled New World lands in the seventeenth and eighteenth centuries, why not the South Australian Association or the New Zealand Company in the nineteenth?

But the appeal to colonial North America was always more than a rhetorical strategy: it also fortified claims to indigenous land. ${ }^{12}$ Just as their Atlantic forebears had dispossessed Native Americans on the grounds that they did not subdue and replenish the earth, so the colonial reformers asserted that the antipodes were unproductive 'waste lands', free for the taking. America thus supplied a rhetorical and juridical justification for company colonization in South Australia and New Zealand, serving both the practical and theoretical needs of these ambitious colonial capitalists.

I begin by examining Edward Gibbon Wakefield's writings on colonization in light of what Onur Ulas Ince has recently termed 'colonial capitalism', the global system of capitalist relations that emerged in the context of the early modern British empire. ${ }^{13}$ America figured prominently in Wakefield's published writings, though the use he made of it was characteristically idiosyncratic. While he drew sustenance and symbolic heft from the exemplar of North American chartered enterprise, he also warned against the destructive impact of dispersion.

The article will then analyse how and why company colonization re-emerged in the antipodes, in particular tracing the repeated rhetorical appeals by the colonial reformers to North American precedent. The recourse to seventeenth- and eighteenth-century North America reveals a paradox at the heart of the systematic colonization of South Australia and New Zealand. While the colonial reformers were eager to invoke the supposed novelty of their theory of colonization, lauding Wakefield for his ingenious system of colonial land management, their textual archive also bears witness to a movement preoccupied with linking their theory to an older, but supposedly lost, tradition of colonization. This was not so much the shock of the new as the reinvention of the old.

The article concludes by unpacking some qualitative differences between the two British settlements, namely the added rhetorical emphasis given by the New Zealand Association and the New Zealand Company to the protection of the islands' original inhabitants, the Māori. It was here, in the context of claiming tribal land, that company colonization clashed most forcibly with indigenous sovereignty, a clash that compelled the colonial reformers to turn to history in an

\footnotetext{
${ }^{10}$ Duncan Bell, Reordering the World: Essays on Liberalism and Empire (Princeton: Princeton University Press, 2016 ), 33.

${ }^{11}$ But see the pioneering essays collected in Kate Fullagar, ed., The Atlantic World in the Antipodes: Effects and Transformations Since the Eighteenth Century (Newcastle upon Tyne: Cambridge Scholars Publishing, 2012). A stimulating special issue on settler colonialism and early modern America has recently been published: see 'Settler Colonialism in Early American History', William \& Mary Quarterly 76 (2019): 361-450.

${ }^{12}$ Lisa Ford, Settler Sovereignty: Jurisdiction and Indigenous People in America and Australia, 1788-1836 (Cambridge, MA: Harvard University Press, 2010); Henry Reynolds, The Law of the Land (Ringwood, Victoria: Penguin, 1987); Paul McHugh, Aboriginal Societies and the Common Law: A History of Sovereignty, Status, and Self-Determination (Oxford: Oxford University Press, 2004).

${ }^{13}$ Onur Ulas Ince, Colonial Capitalism and the Dilemmas of Liberalism (Oxford: Oxford University Press, 2018).
} 
effort to justify their imperial fantasies. But it was also a clash of civilizations that generated its own history, a history where the past now serves to bolster indigenous claims to justice in settler courts. ${ }^{14}$

\section{Systematic colonization and imperial capitalism}

A resurgent wave of scholarship has examined the writings of Edward Gibbon Wakefield (1796-1862), the English political economist and author of the famous A Letter from Sydney. Long recognized as a foundational text in the political economy of empire, Wakefield's Letter profoundly influenced settler colonial discourse throughout the 1830s and 1840s, particularly in relation to South Australia and New Zealand. ${ }^{15}$ First circulated as a pamphlet in 1829, and thereafter published in a series of articles in London's Morning Chronicle, it purportedly described what life was like as a farmer in Britain's farthest colonial outpost, New South Wales. Yet far from being an authentic account of New South Wales, in the tradition of David Collins or Watkin Tench, Wakefield's Letter was actually composed in Newgate Prison, where he was serving a three-year sentence for abducting a wealthy young heiress, Ellen Turner. ${ }^{16}$

Wakefield's core argument was that colonial land should be sold, not granted, and to that end he worked hard to show how wealth in the New World, defined as uncultivated 'waste land', was dependent on concentrated settlement. ${ }^{17}$ A fixation, almost an obsession, with dense settlement tied the otherwise disparate threads of the text together and supplied its analytical thrust, while a strong anti-transportation argument grounded in moral economy underlay a forceful critique of colonial policy in New South Wales and Van Diemen's Land. ${ }^{18}$ If land was simply given away, Wakefield argued, settlers would tend to disperse across the frontier, and his historical sweep of European colonization portrayed in no uncertain terms the damage this wrought: the New World, at least in Wakefield's imperial imaginary, was a desolate place shorn of civilization and the habits of polite society.

Significantly, Wakefield's theory assumed that individual capitalists, not government, would fund colonization, even if a coherent and well-developed account of private colonial enterprise remained unstated until the publication of England and America in 1833, that is to say after various proposals for colonizing South Australia had first been tabled. ${ }^{19}$ But this did not mean that Wakefield wished government to play no part in colonizing Australia. 'It was impossible', he wrote, 'to use waste land without the active assistance of government', as government alone could secure property rights. ${ }^{20}$ But beyond the right of government to lay claim to the antipodes

\footnotetext{
${ }^{14}$ Miranda Johnson, The Land Is Our History: Indigeneity, Law, and the Settler State (Oxford: Oxford University Press, 2016). See also Paul McHugh, Aboriginal Title: The Modern Jurisprudence of Tribal Land Rights (Oxford: Oxford University Press, 2011).

${ }^{15}$ Tony Ballantyne, 'Remaking the Empire from Newgate', in Ten Books that Shaped the British Empire, ed. Antoinette Burton and Isabel Hofmeyr (Durham, NC: Duke University Press, 2014), 29-49; Eric Richards, 'Wakefield Revisited Again', in Foundational Fictions in South Australian History, ed. Carolyn Collins and Paul Sendziuk (Adelaide: Wakefield Press, 2018), 28-42.

${ }^{16}$ This is well covered in the biographical literature on Wakefield. See Ged Martin, Edward Gibbon Wakefield: Abductor and Mystagogue (Edinburgh: Ann Barry, 1997); Philip Temple, A Sort of Conscience: The Wakefields (Auckland: Auckland University Press, 2002).

${ }^{17}$ On the new world as unproductive land, see Alison Bashford and Joyce Chaplin, The New Worlds of Thomas Robert Malthus: Rereading the Principle of Population (Princeton: Princeton University Press, 2016); Allan Greer, 'Commons and Enclosure in the Colonization of North America', American Historical Review 117 (2012): 365-86. On the idea of occupation in Western political thought, see Andrew Fitzmaurice, Sovereignty, Property and Empire, 1500-2000 (Cambridge: Cambridge University Press, 2016).

${ }^{18}$ For Wakefield and convict labour, see John Gascoigne, The Enlightenment and the Origins of European Australia (Cambridge: Cambridge University Press, 2002), 61-6.

${ }^{19}$ Plan of a Company to be Established for the Purpose of Founding a Colony in Southern Australia, Purchasing Land Therein, and Preparing the Land so Purchased for the Reception of Immigrants (London: Ridgway and Sons, 1831).

${ }^{20}$ Ibid.
} 
and specify the much remarked-upon 'sufficient price' on land, government did not figure particularly prominently in Wakefield's plans. ${ }^{21}$

At the heart of Wakefield's argument here was a model of 'colonial capitalism', a vision of colonial expansion underpinned by the productive use of capital. ${ }^{22}$ His capitalist credentials have been insightfully analysed in a recent article in this journal by Gabriel Piterberg and Lorenzo Veracini. ${ }^{23}$ Focusing on Marx's reading of Wakefield, most especially as it concerns the latter's depiction of the Swan River Colony in Western Australia, Piterberg and Veracini claim that Wakefield's theory of colonization heralded the genesis of a previously unplumbed political tradition. Central to this tradition was the assertion that the 'empty lands' of Britain's settler colonies supplied an escape hatch for global capitalism. Insofar as the settler world could be called upon to ward off revolution at home, Piterberg and Veracini argue, the seemingly boundless pastures that they represented acted as a bulwark against social reform.

But it is perhaps worth restating that Wakefield was responding to a live debate in Britain at the time that focused on the relative merits of colonization, not the future prospects of capitalism. Concerned as he was with social decay in Britain and her colonies, Wakefield saw no impending revolution' in the capitalist world system. ${ }^{24}$ More immediate matters pressed on his mind, chief among them the reform of colonial land policy. A recognition of this blunt fact need not cut us off from analysing Wakefield's writings within the framework of global capital, but it does require us to analyse his work in light of the concepts that were open to him as a thinker in the 1820s and 1830s. Thus, whereas Robert Wilmot Horton, the Tory MP and Under-Secretary of State for War and the Colonies between 1821 and 1828, had argued assiduously in favour of the public purse funding mass emigration throughout the $1820 \mathrm{~s}$, Wakefield reframed the emigration and colonization debate so as to foreground the role of private capitalists. ${ }^{25}$ As he noted towards the end of the appendix, 'London capitalists would require no other encouragement to assist in giving effect to the proposed system of colonial policy', for the simple reason that the scheme itself was designed with them in mind. ${ }^{26}$

America supplied the answer for Wakefield, and he turned in particular to American land companies, such as the Ohio Company, for inspiration. The 'mode of selling waste land in North America would furnish a useful model' for the reform of colonial land policy in the antipodes, he noted in the opening point of the appendix that outlined the key principles of systematic colonization, a nod to the Atlantic world that would become common practice by the time that practical proposals for colonizing South Australia began to find their way to the Colonial Office in the early 1830s. ${ }^{27}$ Wakefield was adamant that if his principles were followed, and if the example of contemporary American land companies was emulated, 'Emigration would be carried on by private speculation, not to the loss but to the advantage of those who should defray its expense. ${ }^{.28}$ He argued that what the Ohio Company and the North American Company had achieved in the eighteenth century, British land companies could replicate in the nineteenth.

\footnotetext{
${ }^{21}$ The best account of Wakefield's theory remains that of R. C. Mills. See Mills, Colonization of Australia, 90-139.

${ }^{22}$ Ulas Ince, Colonial Capitalism.

${ }^{23}$ Gabriel Piterberg and Lorenzo Veracini, 'Wakefield, Marx, and the World Turned Inside Out', Journal of Global History 10 (2015): 457-78.

${ }^{24}$ Ibid., 463.

${ }^{25}$ On emigration and colonization, see Edward Kittrell, 'Development of the Theory of Colonization in English Classical Political Economy', Southern Economic Journal 31 (1965): 189-206; Klaus Knorr, British Colonial Theories, 1570-1850 (Toronto: University of Toronto Press, 1944); R. N. Ghosh, 'The Colonization Controversy: R. J. Wilmot Horton and the Classical Economists', Economica 31 (1964): 385-400.

${ }^{26}$ [Edward Gibbon Wakefield], A Letter from Sydney, the Principal Town of Australasia (London: J. Cross, 1829), xvii.

${ }^{27} I b i d$., i-xxiv. On North American land companies, see especially Shaw Livermore, Early American Land Companies: Their Influence on Corporate Development (New York: Octagon Books, 1968).

${ }^{28}$ [Wakefield], Letter from Sydney, vii-viii.
} 
The deployment of America was hardly novel in the tradition of classical political economy. From Adam Smith onwards, America had been regarded as the standard reference point when discussing whether empire was really worth it. Unlike Smith, however, who ploughed the American past for lessons about the wealth of nations and so-called primitive peoples, Wakefield's America operated on two temporal planes, past and present. As both historic object lesson and contemporary case study, America in his work was decidedly Janus-faced, a characteristic that Wakefield exploited to defend both the theoretical principles of systematic colonization and the actual company colonization of South Australia.

There was a further tension underlying Wakefield's depiction of America, however. An amorphous category, America represented both the pinnacle and the pitfalls of colonization. In describing the American frontier, for instance, Wakefield railed against unrestrained settlement: 'But at present, and until they [Americans] can no longer spread, they are, and must remain - like children acquiring the means of knowledge by learning to read - an infant people, acquiring only the means of future wealth and greatness. ${ }^{29}$ At the same time, he also admired the land companies then operating in the Midwestern United States. The more distant American past, on the other hand, the classic period of English colonization, was couched in lofty, even elevated language. After all, it was in the example set by William Penn and Lord Baltimore that Wakefield located the foundations of his own colonial projections. ${ }^{30}$

Such contradictions speak to a sort of creative uncertainty embodied by the image of America. What mattered most to Wakefield and his followers was the strategic use that it served, the practical work that it did in furthering calls for colonial reform. It is this feature of colonial discourse that explains how America was able to operate simultaneously as the subject of scorn and adulation. Highly stylized, the impressions of America that flowed from Wakefield's pen took shape with one eye firmly fixed on colonial strategy. It was a conceptual and historical device that was constantly moulded and remoulded to fit the imperatives of systematic colonization. This was a polyphonic America, an America to be used as one saw fit.

England and America was exemplary in looking to America as both model and deterrent. Published at the very moment when the colonial reformers were lobbying Downing Street, Wakefield's magnum opus wove support for the South Australian Land Company into its more conventional analysis of North American political economy. ${ }^{31}$ Drawing in particular on James Stuart's two-volume Three Years in North America (1833), Wakefield described a continent that was bereft of any signs of refinement: prone to religious zealotry, blighted by bigotry, hostile to learning and self-improvement. Civilization this was not, and he attributed this to the superabundance of land that encouraged settlers to take up their own homesteads, rather than work as hired labour, a point he also made in relation to Spanish America, and one that marked his writings out from Adam Smith. ${ }^{32}$ As Wakefield had noted earlier in A Letter from Sydney, his citation of Smith's Wealth of Nations was akin to taking the 'bull by its very horns', for Smith 'argues in favour of excess territory', whereas he of course argued forcefully in favour of concentrated settlement. ${ }^{33}$

\footnotetext{
${ }^{29}$ Ibid., 163.

${ }^{30}$ This point is discussed at length below.

${ }^{31}$ [Edward Gibbon Wakefield], England and America: A Comparison of the Social and Political State of Both Nations, vol. 2 (London: Richard Bentley, 1833).

${ }^{32}$ Ibid.

${ }^{33}$ [Wakefield], Letter from Sydney, 151. Wakefield published a four-volume edition of Smith's Wealth of Nations while he was actively engaged in colonial speculation. See Adam Smith, An Inquiry into the Nature and Causes of the Wealth of Nations, ed. Edward Gibbon Wakefield, 4 vols. (London: Charles Knight, 1835-40). On Wakefield's engagement with Smith, see Erik Olssen, 'Wakefield and the Scottish Enlightenment, with Particular Reference to Adam Smith and his Wealth of Nations', in Edward Gibbon Wakefield and the Colonial Dream: A Reconsideration (Wellington, GP Publications, 1997), 47-66. On Smith and empire, see Emma Rothschild, 'Adam Smith in the British Empire', in Empire and Modern Political Thought, ed. Sankar Muthu (Cambridge: Cambridge University Press, 2012), 184-98; Sankar Muthu, 'Adam Smith's Critique of International Trading Companies: Theorizing “Globalization” in the Age of Enlightenment', Political Theory 36 (2008): 185-212.
} 
And yet America also supplied hope, or at least a model that could be revived in South Australia. While contemporary American land companies were cited as exemplars of prudent capitalist enterprise, the empirical evidence that demonstrated the merits of selling colonial waste land, it was the American past that most moved Wakefield. He asserted that 'The old English colonies in America, now the eastern States of the Union, were not founded by any government. They were founded by individuals, not even aided by any government, save as the compact, into which each of those bodies of individuals entered, was bound by a charter from the crown of England. ${ }^{34}$ From Virginia to Maryland, Baltimore to North Carolina, this was an English past that spoke powerfully in favour of chartered colonial enterprise, a uniquely virtuous mode of colonization.

Just as George Fife Angas would later model himself on William Penn, the notable Quaker founder of Pennsylvania, so Edward Gibbon Wakefield saw himself as upholding a peculiarly English tradition of private colonial enterprise. ${ }^{35}$ In an unpublished manuscript held at Archives New Zealand/Te Rua Mahara o te Käwanatanga, which was most likely written in 1846, after attempts to systematically colonize South Australia, Wakefield reflected at length on the colonization of North America, arguing that England's chartered colonies of the seventeenth century embodied the highest principles in the art of colonization, certainly far superior to those practised by the French or Spanish. 'The old proprietary authorities', he claimed in a crossed-out passage, 'whether individuals or corporations, almost invariably exhibited the greatest earnestness and attained a great success as respects the first stage of colonization, and none more than the joint stock company for founding Carolina, the directors of which were chiefly Cabinet Ministers.' 36

Wakefield stopped short, however, of openly championing the company model in A Letter from Sydney, only fleshing out his arguments about chartered colonial enterprise in later writings. ${ }^{37} \mathrm{His}$ influential theory, in its first iteration, advocated private colonial enterprise but refrained from endorsing company colonization explicitly. This was a vision of empire that imagined the redundant poor tilling antipodean pastures for the benefit of metropolitan capitalists, a fact that no less an authority than Karl Marx noted, even if he had relatively little to say about companies. ${ }^{38}$ 'The whole object of the proposed measure', wrote Wakefield, 'is to diminish the evils of pauperism in Britain, and to promote colonization, by rendering the purchase of waste land a very profitable employment of capital. ${ }^{39}$ Only then, he argued, could the New World benefit both colony and metropole. Thus, at the theoretical level of political economy, companies and colonial reform were not yet conjoined: that fusion unfolded in the practical act of colonizing South Australia. The next section of this article will analyse how systematic colonization as a general theory of colonial capitalism was transformed into a more specific set of arguments that advocated company colonization.

\footnotetext{
${ }^{34}$ [Wakefield], England and America, 2:241.

${ }^{35}$ Angas's personal archive is full of references to Penn, including a number of neatly collated newspaper articles. See PRG 174 11, George Fife Angas Papers, State Library of South Australia, Adelaide.

${ }^{36}$ The manuscript bears no title. It seems likely that it was written in the context of debates between the New Zealand Company and the Colonial Office over the New Zealand Constitution Act 1846 (9 \& 10 Vict. c. 103). See NZC 31/33, New Zealand Company Papers, Archives of New Zealand, Wellington. For a contemporary restatement of Wakefield's views, see the printed extracts of his correspondence with William Gladstone in the New Zealand Journal, the company's mouthpiece: Edward Gibbon Wakefield to William Gladstone, 21 January 1846, New Zealand Journal 6 (London: Stewart and Murray, 1846), 126-30.

${ }^{37}$ See the next section for a discussion of England and America, Wakefield's most substantial statement on the political economy of colonization.

${ }^{38}$ Karl Marx, Capital: A Critique of Political Economy, vol. 1, trans. Ben Fowkes (London: Penguin, 1990), 932; H. O. Pappe, 'Wakefield and Marx', Economic History Review 4 (1951): 88-97; Piterberg and Veracini, 'Wakefield, Marx, and the World Turned Inside Out', 457-78.

${ }^{39}$ [Wakefield], Letter from Sydney, xvi.
} 


\section{Visions of America and colonial reform}

Colonial North America was a constant reference point in the colonization of South Australia, as it was in New Zealand towards the end of the decade. If the Swan River Colony (1829) in Western Australia was the model to avoid, the antipodean case study in the rear view that showed how it could all go wrong, North America was another benchmark, the epitome of colonial success. In the years that followed the publication of Wakefield's Letter from Sydney, a number of proposals to colonize South Australia were submitted to the Colonial Office by various private organizations, among them the South Australian Land Company, the South Australian Association, the South Australian Colonisation Commission, and the South Australian Company. ${ }^{40}$

But while the early history of South Australia has long been analysed, how and why the colonial reformers invoked North American precedent has been overlooked. Regional histories have frequently emphasized South Australia's origins as a 'free colony', untainted by convict transportation, while the broader political and religious inclinations of the colony's early founders and settlers has also been regularly assessed, particularly in relation to the 1834 South Australia Act. ${ }^{41}$ Yet visions of America were deeply bound up with visions of colonial reform, and the conjuring up of North American precedent was all but ubiquitous in the context of practical plans to form a British settlement in South Australia.

In 1831 a plan to colonize South Australia was penned and submitted to the Colonial Office by representatives of the South Australian Land Company, thus connecting company colonization and colonial reform for the first time. ${ }^{42}$ Nominating modern American land companies as the example par excellence, this stripped-back plan envisaged the replication of North American land speculation in the antipodes, foregoing the sort of sweeping survey of chartered rights and privileges that accompanied subsequent rhetorical appeals to America. This was strictly an analogy of business practice, and company structure was thus kept at the forefront. The Canada Company was also identified as a prototype, a paragon of company colonization success to which both the Van Diemen's Land Company and the South Australian Company turned for guidance. ${ }^{43}$

\footnotetext{
${ }^{40}$ This article does not analyse the South Australian Company, the joint-stock land company established by George Fife Angas in 1835. But my broader project seeks to write this unduly neglected company back into the history of antipodean land settlement.

${ }^{41}$ Shaun Berg, ed., Coming to Terms: Aboriginal Title in South Australia (Kent Town, SA: Wakefield Press, 2010); Pike, Paradise of Dissent; Robert Foster and Paul Sendziuk, A History of South Australia (Melbourne: Cambridge University Press, 2018). For the South Australia Act, see G. L. Fischer, 'South Australian Colonization Act and Other Related Constitutional Documents', Adelaide Law Review 2 (1966): 360-72; P. A. Howell, 'The South Australia Act, 1834', in The Flinders History of South Australia: Political History, ed. Dean Jaensch (Adelaide: Wakefield Press, 1986).

${ }^{42}$ Plan of a Company. Jeremy Bentham also drafted a charter to underwrite the company colonization of South Australia, most likely under the influence of Wakefield. See Jeremy Bentham, 'Colonization Company Proposal: being a Proposal for the formation of a Joint-Stock Company by the name of the Colonization Company on an entirely new principle intituled the Vicinity maximizing or Dispersion-preventing principle', 1831, Box 8, Bentham Papers, University College London Special Collections, London. Bernard Semmel notes that Wakefield had sent Bentham his 'Sketch of a Proposal for Colonizing Australasia' from Newgate. The British Museum copy purportedly bears the inscription 'Jeremy Bentham [13 July 1829] Received From the unknown author/without accompanying Note'. See Semmel, Rise of Free Trade Imperialism, 93. Bentham had argued strongly against transportation in Panopticon versus New South Wales (1812). See Jennifer Pitts, 'Legislator of the World? A Rereading of Bentham on Colonies', Political Theory 31 (2003): 200-34; John Gascoigne, The Enlightenment and the Origins of European Australia (Cambridge: Cambridge University Press, 2014), $123-31$.

${ }^{43}$ Charles Tennant, Letters Forming Part of a Correspondence with William Nassau Senior, Esq. Concerning Systematic Colonisation, and the Bill Now Before Parliament for Promoting Emigration; also, a Letter to the Canada Land Company, and a Series of Questions, in Elucidation of Principles of Colonization (London: Ridgway, 1831), 91. The Van Diemen's Land Company instructed its agent in Tasmania to study the Canada Company, particularly in relation to tenant farming. They sent Edward Curr, the resident agent, a copy of William Cattermole's Advantages of Emigration to Canada: Being the Substance of Two Lectures Delivered at the Town-Hall, Colchester, and the Mechanics' Institution Ipswich (London: Simpkin and Marshall, 1831). See VDL 193/1/2, Van Diemen's Land Company Papers, Archives Office of Tasmania, Hobart. The South Australian Company also modelled themselves on the Canada Company. See also South Australian Company Prospectus, 1836, South Australian Company Papers, BRG 42 14, State Library of South Australia, Adelaide.
} 
But if the initial plan was framed in light of the American present, the charter submitted to the Colonial Office in 1832 found sustenance in the colonial past. With the significant exception of the Swan River Colony in Western Australia, the new proposal confidently stated that all 'our old and most successful colonies' depended on individual industry and private capital for success, not government oversight: 'For the partial failure of the Swan River settlement, the Government who founded the settlement without any provision for success, is, no doubt, responsible; but then Plymouth and William Penn, - not the Governments of the time, - were responsible for the success of the colonies of Virginia and Pennsylvania. ${ }^{44}$

The Virginia Company may be a dubious model of colonial success, but that overlooks the discursive function that it performed for contemporaries, the weight attached to North American chartered enterprise by those invested in creating new colonies in the second quarter of the nineteenth century. ${ }^{45}$ Swan River, in no small part thanks to Wakefield, was by the early 1830s synonymous with colonial failure, starvation rather than success. ${ }^{46}$ The old company model of the seventeenth century, by contrast, was a tried and tested method for settling English people on New World lands. Company colonization, in other words, may have been a lost art but it was also one that could be resurrected to avert the horrors of the Swan River Colony or the equally abhorrent system of convict transportation then in operation in New South Wales and Van Diemen's Land.

There were, of course, substantive critiques of company colonization in South Australia, and the question of whether the company could claim imperium loomed large in early discussions between the South Australian Land Company and the Colonial Office. The Colonial Office was clear that the charter devolved far too much authority to the company. As the Permanent Under-Secretary of State for War and the Colonies, Robert Hay, remarked to Robert Torrens on 17 July 1832, the charter 'would virtually transfer to this company the sovereignty of a vast unexplored territory, equal in extent to one of the most considerable kingdoms of Europe', an argument also tendered by James Stephen in one of his characteristically insightful memoranda. ${ }^{47}$ Going straight to the heart of the matter, Stephen, the influential legal adviser to the Colonial Office, dismissed as folly the likeness that the company drew between themselves and England's seventeenth-century corporate ventures, effectively erasing the connection that the company had rhetorically forged between antipodean and Atlantic company colonization. ${ }^{48}$

Stephen acidly asserted that the company's plan was akin to 'settling a republic within a monarchy', an unthinkable affront to the integrity of the British constitution. The by then scurrilous example of the East India Company was also cited, with Stephen drawing on the history of the Indian empire to refute the South Australian Land Company's purported claim to be acting in the public interest. 'They were', he stated, simply 'Gamblers playing for a high stake', oblivious

\footnotetext{
${ }^{44}$ J. E. Strickland to Lord Goderich, 18 June 1832, CO 13/1, The National Archives, Kew, UK (hereafter cited as TNA).

${ }^{45}$ For an excellent intellectual history of the Virginia Company, see Andrew Fitzmaurice, Humanism and America: An Intellectual History of English Colonisation, 1500-1625 (Cambridge: Cambridge University Press, 2003).

${ }^{46}$ J. M. R. Cameron, 'Information Distortion in Colonial Promotion: The Case of Swan River Colony', Australian Geographical Studies 12 (1974): 57-76.

${ }^{47}$ Copy of a letter from R. W. Hay to Robert Torrens, 17 July 1832, TNA, CO 13/1; James Stephen, Memorandum, 14 July 1832, TNA, CO 13/1. On Robert Torrens and company colonization in New Zealand, see Shaunnagh Dorsett, 'Metropolitan Theorising: Legal Frameworks, Protectorates and Models for Maori Governance 1837-1838', Law and History 3 (2016): 1-27. On Torrens and South Australia, see Lionel Robbins, Robert Torrens and the Evolution of Classical Economics (London: Macmillan and Co., 1958), 144-81.

${ }^{48}$ Stephen, Memorandum, 14 July 1832, TNA, CO 13/1. See also Stephen's discussion of America in GRE/B126/11 and GRE/B126/12, Henry George Grey, 3rd Earl Grey Papers, Special Collections, Durham University Library, Durham. In a letter from Stephen to Grey, Stephen reflects at length on the applicability of North American precedent: 'Commentators on colonial or any other history who confine themselves to official documents are as sure to go awry as if they entirely overlooked them. In the book containing the charters of the old N. American colonies they are put forward as specimens of proposed wisdom and liberality by those who either do not or will not look further than the four corners of those parchments.' See James Stephen to Earl Grey, 14 March 1850, GRE/B126/12.
} 
to the wider social concerns that pressed so heavily upon the overworked and chronically underresourced Colonial Office. ${ }^{49}$ Though far from opposed to companies in principle, Stephen and the Colonial Office were nevertheless careful to avoid endorsing the erection of unfettered companystates, corporate entities beholden to no-one but their own sovereign authority, as well they might be. ${ }^{50}$ The Colonial Office argued that the South Australian Land Company was perfectly entitled to purchase land in South Australia according to the Wakefield model, but its powers as a corporation would be limited to land sales. ${ }^{51}$

The South Australian Association, which was formed in late 1833, articulated perhaps the most ambitious colonial agenda among the plethora of bodies formed in the years that followed Wakefield's Letter from Sydney. Like the South Australian Land Company, the association sought a charter, yet it invoked the model of North America more forcibly than its predecessor. Composed of well-connected and influential individuals, many with links to the City of London and Westminster, among them George Grote, the philosophical radical and well-known historian of ancient Greece, and Robert Gouger, by then a well-established figure among metropolitan land speculators, the association was a powerful lobby for colonial reform. ${ }^{52}$ If the South Australian Land Company's plan was plain, even bald, the South Australian Association's prospectus was bold. Published in early 1834, it was well received and widely covered in the London press. And it was also much enamoured with the English colonization of America:

All the old and most successful British colonies in North America - Virginia, Massachusetts, Connecticut, Rhode Island, Pennsylvania, Maryland, and Georgia - were founded by individuals whose public spirit, prudence, and resolution were not otherwise assisted by the Government of this country, than as a charter from the Crown erected each of those bodies of individuals into a corporation, with the authority required for accomplishing, to use the words of those charters, 'their generous and noble purpose'.

In this respect, the South Australian Association, confiding in the paternal goodness of his present Majesty, and trusting that their undertaking will be favourably viewed by an enlightened and liberal administration, will endeavour to follow the example of the London and Plymouth companies, which founded Virginia; of William Penn and his companions, who founded Pennsylvania; of Lord Baltimore and his associates, who founded Maryland; and of Lord Perceval and his co-trustees, who established the colony of Georgia. ${ }^{53}$

Gouger's appeal to company colonization in North America, however, went far beyond simply summoning up the names of William Penn, Lord Baltimore, and Lord Perceval. His explanation of the South Australian Association's guiding principles, for example, was buttressed by a lengthy citation from the 1732 Charter of Georgia, even going so far as to claim that the American charter embodied the essential aims of the antipodean association: 'The following extracts from the Georgian Charter will, in some measure, explain the objects of the South Australian Association, and the means by which it is proposed to accomplish them.' But the example of Georgia also served a functional purpose. Aside from drawing on the same assumptions about

\footnotetext{
${ }^{49}$ Stephen to Grey, 14 March 1850, GRE/B126/12, Durham University Library. On James Stephen and the Colonial Office, see A. G. L. Shaw, 'James Stephen and Colonial Policy: The Australian Experience', Journal of Imperial and Commonwealth History 20 (1992): 11-34; Paul Knaplund, James Stephen and the British Colonial System, 1813-1847 (Madison: University of Wisconsin Press, 1953).

${ }^{50}$ Knaplund, James Stephen, 487. On the idea of the 'company-state', see Philip J. Stern, The Company-State: Corporate Sovereignty and the Early Modern Foundations of the English Empire in India (New York: Oxford University Press, 2011).

${ }^{51}$ James Stephen, Memorandum 'South Australian Land Company', 20 December 1832, TNA, CO 13/1.

${ }^{52}$ South Australian Association Prospectus (London: W. Nicol, 1834), enclosed in TNA, CO 13/2. See also Edwin Hodder, The History of South Australia: From its Foundation to the Year of the Jubilee, with a Chronological Summary of All the Principal Events of Interest up to Date (London: Sampson Low, 1893), 26.

${ }^{53}$ South Australian Association Prospectus.
} 
indigenous land, namely that South Australia was waste or desert, free for the taking, Gouger and the South Australian Association also modelled themselves on the corporate structure of the Trustees of Georgia, who were 'one body politic and corporate, in deed and name' ${ }^{54}$

Historians of South Australia have tended to argue that the colony was distinct, that it was an outlier in the antipodes, yet that is not how the very actors involved in attempts to found the colony saw themselves, and nor should it be how we subsequently interpret them. What Gouger's reference to Georgia shows, and what George Grote's related historical rendition over a two-century sweep of chartered colonial enterprise, from 1578 to 1791, reaffirms, is the imaginative and substantive power that the revival of English colonial history over the long run performed for these aspirational colonial capitalists. ${ }^{55}$ Yet this constant shuffling back and forth between the Atlantic and the antipodes also reveals a paradox deeply embedded in the systematic colonization of South Australia. The colonial reformer's plans may have been novel in the context of what they called modern colonial policy - that is to say, post-1776 British colonial land settlement - but it was also derived from the Elizabethan 'golden age' of exploration and settlement in North America. The Indian ocean new world was in this sense imaginatively constructed from retrospective impressions of its Atlantic counterpart.

Just as the South Australian Association made overtures to North American precedent, the South Australian Colonisation Commission, which oversaw land sales and emigration in the nascent colony, turned to the seventeenth-century Atlantic for validation and legitimacy. ${ }^{56}$ In what was almost certainly a calculated rhetorical move, the Colonisation Commission issued a draft charter that ranged broadly over English colonial history, tracing chartered enterprise from its origins until the close of the eighteenth century, the high point of European exploration in the Pacific Ocean. ${ }^{57}$ The purpose of situating their plans in a long tradition of private colonial enterprise not only imbued the Colonisation Commission's scheme with a sense of prestige, however: it also justified the principles that underwrote it. If the English had successfully colonized New World lands in the Americas with charters in the seventeenth and eighteenth centuries, why could those on the cusp of settling a new colony in South Australia in the nineteenth not follow suit? English colonial history was thus a symbolic reservoir that could be tapped to supply authority in the present, a past that could be dredged up in the act of extolling the virtues of a far-reaching colonial agenda.

Yet the draft charter had a more ambitious goal than simply authorizing the South Australian Commission's scheme rhetorically, however powerful or grand that appeal may have been. At stake, as so often in the antipodes during the 1830 s and 1840 s, was the very real question of dominium. ${ }^{58}$ Who had it, and by what means? The template of colonization bequeathed by Wakefield to the South Australian Association, as already noted, was founded on two assumptions: first, that Aboriginal country was unproductive waste land, a terra nullius in all but name; second, that private enterprise was the appropriate vehicle of colonial reform. ${ }^{59}$ The model of North American colonization, as captured by the draft charter, adhered to both prescriptions and could therefore

\footnotetext{
${ }^{54}$ Ibid.

${ }^{55} \mathrm{TNA}, \mathrm{CO}$ 13/2. On colonial charters in the Atlantic world, see Elizabeth Mancke, 'Chartered Enterprises and the Evolution of the British Atlantic World', in The Creation of the British Atlantic World, ed. Elizabeth Mancke and Carole Shammaseds (Baltimore: The Johns Hopkins University Press, 2005).

${ }^{56}$ The classic study of the South Australian Colonisation Commission remains Douglas Pike's Paradise of Dissent, 169-95. But see more recently, Bain Attwood, 'Returning to the Past: The South Australian Colonisation Commission, the Colonial Office and Aboriginal Title', Journal of Legal History 34 (2013): 55-9.

${ }^{57}$ Draft of a Proposed Charter for the South Australian Commission with some Introductory Remarks (London: William Nicol, 1834).

${ }^{58}$ Bain Attwood, 'Law, History and Power: The British Treatment of Aboriginal Rights in Land', Journal of Imperial and Commonwealth History 42 (2014): 171-92.

${ }^{59}$ It is important to note that the term terra nullius was not used to justify the colonization of Australia and New Zealand. The concept was first deployed in the context of late nineteenth-century debates over the polar regions. See Andrew Fitzmaurice, 'The Genealogy of Terra Nullius', Australian Historical Studies 38 (2007): 1-15.
} 
be used by the commission to fortify their claims to indigenous land. 'The plantation of a colony, that is, the establishment of society on a distant and desert spot', the draft charter stated, 'requires the exercise of the highest of those governing or sovereign powers by which society is anywhere maintained. ${ }^{60}$ Like the Trustees of Georgia, whose 1732 charter had been cited at length by the South Australian Association in its 1834 prospectus, or the colonists of Massachusetts, the commission demanded the sovereign authority to lay claim to unoccupied land, an act that the commission deemed inconceivable without chartered rights. ${ }^{61}$ 'It was impossible', the commission argued, 'that those private persons should carry their purpose into effect without obtaining powers sufficient to constitute and uphold society in a distant place. ${ }^{62}$ The implication was clear: if the Colonial Office was not prepared to grant the commission sovereign authority, the colony would not be founded.

The undivided sovereign authority that the charters conferred on the colonists of North America was precisely the sort of power that the South Australian Colonisation Commission sought for itself, a yearning borne out by lengthy citation and commentary upon England's old colonial charters. 'We find, accordingly, that every one of the charters of our old colonies in America erected a kind of sovereignty, bestowing upon a single person, or several persons incorporated as one, a degree of authority which was supreme, so far as related to the country about to be colonized. ${ }^{63}$ The North American charters thus had legal as well as rhetorical significance; indeed, the two were intertwined. The almost deferential way in which the world of William Penn and the Virginia Company was summoned up in the practical task of soliciting the Colonial Office's sanction for the systematic colonization of South Australia reveals much about how they understood their own ventures. The contexts of colonial North America in the seventeenth century and South Australia in the year of the New Poor Law, 1834, may have been separated by a hemisphere and nigh on two hundred years of history, but that did not render visions of America any less intoxicating for ambitious individuals actively engaged in thinking through the space between the political economy of colonization and actual antipodean land settlement.

\section{Chartered enterprise in the islands of New Zealand}

The discursive appeal of North America also cast a mesmeric grip on the New Zealand Company, a joint-stock land company established in 1839. Furnished with eight volumes of American charters, along with contemporary company prospectuses and a smattering of classic texts on the history of corporations, the New Zealand Company figuratively bestrode both the Atlantic and the Pacific worlds. ${ }^{64}$ This was not a company without forebears: they saw themselves as heirs to an honourable, even glorious, tradition of chartered colonial enterprise. William Hutt, a member of the South Australian Colonisation Commission and the 1840 Western Australian Company, certainly thought so. ${ }^{65}$ Writing to the Colonial Office on behalf of the New Zealand Company in early

\footnotetext{
${ }^{60}$ Draft of a Proposed Charter for the South Australian Commission.

${ }^{61}$ Ibid. On colonial Georgia, see Albert B. Saye, A Constitutional History of Georgia, 1732-1945 (Athens, GA: University of Georgia Press, 1948); Ford, Settler Sovereignty; Trevor Richard Reese, Colonial Georgia: A Study in British Imperial Policy in the Eighteenth Century (Athens, GA: University of Georgia Press, 1963).

${ }^{62}$ Draft of a Proposed Charter for the South Australian Commission.

${ }^{63}$ Ibid.

${ }^{64}$ The New Zealand Company's library, for instance, contained a copy of Stewart Kyd's A Treatise on the Law of Corporations, 2 vols. (London: J. Butterworth, 1793-94), as well as papers relating to the Hudson's Bay Company. See TNA, CO 209/120.

${ }^{65}$ The Western Australian Company is little studied, but see Angela Woollacott, Settler Society in the Australian Colonies: Self-Government and Imperial Culture (Oxford: Oxford University Press, 2015), 50-66; J. M. R. Cameron, 'The Rise and Fall of the Western Australian Company', in The Australind Letters of Marshall Waller Clifton, ed. J. M. R. Cameron and P. A. Barnes (Carlisle: Hesperian Press, 2017).
} 
1839, Hutt demanded, 'in accordance with the ancient precedents, a Charter of Government for the Islands of New Zealand'. ${ }^{66}$

Yet it was not just the New Zealand Company who invoked America. The Colonial Office also turned to North America for guidance, citing America in its discussions with the New Zealand Company's predecessor, the New Zealand Association. Although they dismissed the association's appeal for an Act of Parliament, the source of much trouble and consternation in South Australia, they acknowledged that they were 'willing to consent to the Incorporation by a Royal Charter, of various persons to whom the settlement and government of the projected colony, for some short time of years would be confided'. ${ }^{67}$ But what sort of charter would it be? How would it be drafted?

Lord Glenelg, Secretary of State for the Colonies, endorsed Lord Durham's suggestion that a brief study of British history would yield the answer: 'The charter would be framed with reference to the precedents of the Colonies established in North America by Great Britain in the sixteenth and seventeenth centuries. ${ }^{26}$ The North American model was even begrudgingly endorsed by James Stephen, stern critic of the analogy drawn by the South Australian Colonisation Commission between Atlantic and antipodean company colonization:

I, therefore, adhere to the opinions communicated by Lord Durham in the spring of last year. They were in substance that a Colony should be formed on the model of the old New England Constitutions, that is, as a Body Corporate with a joint stock, the management of that stock being the business of the Governing Body in England - the Settlement and Government of the Colony being the business of the Corporation abroad. ${ }^{69}$

But whereas North America was invoked solely by advocates of colonization in South Australia, in New Zealand the lessons of colonial history were also conjured up by those seeking to protect Māori. ${ }^{70}$

The Church Missionary Society, a significant presence in the islands of New Zealand since 1814, thus cited a stream of North American charters to argue that Europeans had habitually cloaked their ambitions behind a veil of good intentions, a veil that, once lifted, ultimately left behind nothing but broken promises. ${ }^{71}$ One of the Society's pamphlets ran:

It is all the more necessary that the proposals of the Association should be submitted to a strict investigation, because in some of the earliest colonizing schemes, the greatest anxiety was manifested for securing the interests of the natives, and their advancement in civilization; and yet even those have not formed any exceptions to the general rule, on which the benevolent mind can dwell with satisfaction. ${ }^{72}$

Allusion to the charters of Virginia and Connecticut thus worked to fold the New Zealand Association's plans into a narrative of European conquest over the non-Christian world, a stark

\footnotetext{
${ }^{66}$ William Hutt to Lord Normanby, 20 February 1839, TNA, CO 209/4.

${ }^{67}$ Lord Glenelg to Lord Durham, 29 December 1837, MS-Papers-0140-02, J. G. Lambton Papers, Alexander Turnbull Library, Wellington.

${ }^{68} \mathrm{Ibid}$.

${ }^{69}$ James Stephen, Memorandum, 15 March 1839, TNA, CO 209/4.

${ }^{70}$ Bain Attwood, 'Protection Claims: The British, Maori and the Islands of New Zealand, 1800-40', in Protection and Empire: A Global History, ed. Lauren Benton, Adam Clulow, and Bain Attwood (Cambridge: Cambridge University Press, 2018), 153-74.

${ }^{71}$ On the Church Missionary Society, see Tony Ballantyne, Entanglements of Empire: Missionaries, Māori, and the Question of the Body (Auckland: Auckland University Press, 2015). See also Judith Binney, 'Christianity and the Maoris to 1840: A Comment', New Zealand Journal of History 3 (1969): 143-65.

${ }^{72}$ John Beecham, Colonization: Being Remarks on Colonization in General, with an Examination of the Proposals of the Association which has been formed for Colonizing New Zealand (London: James Nichols, 1838), 222. The pamphlet is located in TNA, CO 209/3.
} 
illustration of how chartered enterprise in the Pacific had disturbing resemblances to its Atlantic predecessor. ${ }^{73}$ If the Virginia Company had left behind a legacy tainted by the extermination and forcible removal of Native Americans, the Church Missionary Society argued, what was so different this time around? Had the British not been here before? The texture of the debate in New Zealand therefore had added complexity, given the far more serious consideration of Māori. Whereas the South Australian Commission repeatedly declared that the antipodes were 'waste' and 'unoccupied', the New Zealand Association acknowledged that the 'New Zealanders', denoting Māori, already inhabited some of the island's territory, a qualified acknowledgement that Māori possessed the right of occupation over specific tracts of land. ${ }^{74}$

But the acknowledgement that parcels of the islands were occupied by Māori was far from extraordinary, particularly given the flow of pen and paper between Britain and the antipodes since James Cook's circumnavigation of New Zealand in $1769-70 .{ }^{75}$ What was extraordinary, however, was the emphasis that the New Zealand Association placed on 'civilizing' Māori. ${ }^{76}$ Unlike the South Australian Commission, the association's plan emphasized the benefits of systematic colonization for both settler and native. ${ }^{77}$ It was, in other words, a plan that made provision for both the would-be British 'barbarian' and the supposedly 'savage' Māori.

While Wakefield believed that New Zealand had been taken into British possession by virtue of Cook's 'discovery' of the islands in 1769 , he was equally clear that this right did not hold sway over the indigenous Māori. ${ }^{78}$ The doctrine of discovery only furnished Britain with a right of acquisition in relation to European competitors, those self-styled 'civilized' societies that defined the law of nations in contradistinction to the heathen and barbaric extra-European world. ${ }^{79}$ In 'these times', Wakefield argued, Britain's right to the antipodes was not something that could simply be presumed, an argument he would later disown under parliamentary scrutiny. ${ }^{80}$ The prior occupation of the islands by Māori meant that the New Zealand Association would have to consult iwi (tribes): land could only be legitimately obtained via 'treaty with the native inhabitants' ${ }^{81}$

This qualified admittance of Māori into the law of nations was reinforced by the New Zealand Association's claim that the islands constituted an independent country (a claim that Wakefield strikingly retracted in testimony before the 1840 Select Committee on New Zealand) ${ }^{82}$ The association pointed out that the British government had both formally and informally recognized the

\footnotetext{
${ }^{73} \mathrm{Ibid}$.

${ }^{74}$ [Edward Gibbon Wakefield], A Statement of the Objects of the New Zealand Association, with some Particulars Concerning the Position, Extent, Soil and Climate, Natural Productions, and Natives of New Zealand (London: John W. Parker, 1837), $18-19$.

${ }^{75}$ On Cook's Pacific voyages, see Anne Salmond, The Trial of the Cannibal Dog: Captain Cook in the South Seas (London: Allen Lane, 2003); Nicholas Thomas, Discoveries: The Voyages of Captain Cook (London: Allen Lane, 2003).

${ }^{76}$ On the New Zealand Association and race, see Salesa, Racial Crossings, 30-3.

${ }^{77} \mathrm{But}$ it is important to note that the 1836 Letters Patent, which established the Province of South Australia, explicitly recognized Aboriginal occupation. The relevant passage reads as follows: 'Provided Always that nothing in those our Letters Patent contained or shall affect or be construed to affect the rights of any Aboriginal Natives of the said Province to the actual occupation or enjoyment in their own Persons or in the Persons of their Descendants of any Lands therein now actually occupied or enjoyed by such Natives.' For an insightful discussion of the Colonisation Commission and the Letters Patent, see Attwood, 'Returning to the Past', 67-73.

${ }^{78}$ [Wakefield], Statement of the Objects of the New Zealand Association, 3. For a rereading of the doctrine of discovery from an indigenous perspective, see Robert J. Miller, Jacinta Ruru, Larissa Behrendt, and Tracey Lindberg, eds., Discovering Indigenous Lands: The Doctrine of Discovery in the English Colonies (Oxford: Oxford University Press, 2010).

${ }^{79}$ Saliha Belmessous, 'The Treaty of Waitangi in Historical Context', in Indigenous Peoples and the State: International Perspectives on the Treaty of Waitangi, ed. Carwyn Jones and Mark Hickford (Routledge: Oxford, 2018), 77-93. For a magisterial study of international law in imperial context, see Jennifer Pitts, Boundaries of the International: Law and Empire (Cambridge, MA: Harvard University Press, 2018).

${ }^{80}$ [Wakefield], Statement of the Objects of the New Zealand Association, 3-4.

${ }^{81}$ Ibid.

${ }^{82}$ 'Report from the Select Committee on New Zealand; Together with the Minutes of Evidence Taken Before Them, and an Appendix, and Index', in British Parliamentary Papers 1840 (582), 44.
} 
'independence' of Māori. ${ }^{83}$ In one of the association's pamphlets, for instance, Wakefield alluded to the fact that the government had appointed a British Resident, James Busby, in 1832, who had subsequently commissioned a national flag for the United Tribes of New Zealand, in $1834 .^{84}$

Wakefield's repeated insistence that Māori had a legitimate right to the land they occupied represented a significant break from his earlier assumptions about colonial waste land in both A Letter from Sydney and England and America, fundamentally reshaping how the New Zealand Association perceived its rights in relation to Māori. Until Māori had ceded the entirety of their land to the Crown, the association's argument ran, the country would have to be treated as though it were a foreign nation under the law of nations; the gradual extension of British sovereignty over the islands of New Zealand would thus have to be pursued through negotiation.

But the nominal acquisition of British sovereignty in 1840 under te Tiriti o Waitangi/the Treaty of Waitangi did not put an end to the debate over sovereignty, property, and empire. ${ }^{85}$ In evidence given before the 1840 select committee, Wakefield drew on the law of nations and stadial theory to justify the New Zealand Company's land purchases from Māori. ${ }^{86}$ It marked a stunning volte-face. Whereas Wakefield had previously argued for the need to treat with Māori, here he distanced himself from those earlier remarks. He now maintained that the Treaty of Waitangi was a 'mockery', just like the 1835 Declaration of Independence which recognized the sovereign status of the United Tribes of $\mathrm{Nu}$ Tirene (New Zealand). ${ }^{87}$

What explains this sudden shift? What accounts for the tension between the stance adopted by the New Zealand Association in 1837 and the oral testimony of Wakefield before the parliamentary select committee just three years later? A frank assessment of the post-Waitangi political landscape by Wakefield and the New Zealand Company seems to be the most plausible explanation for this seeming contradiction. Testament to the malleable nature of ideas in colonial contexts (which often underwent modification and recalibration in line with strategic ends), the 1840 utterance speaks to a concern with Crown pre-emption. Anxious that recognition of Crown sovereignty would invalidate the company's prior claims, Wakefield's new position appears designed to show that the company was entirely justified in purchasing land from iwi.

At stake was the very viability of the New Zealand Company. Having hitched itself so intimately to the ideas of systematic colonization, the company now faced an existential threat. The directors worried that, if Crown pre-emption was accepted, they would not have a valid title to land, the very commodity that their business model depended on. Assessed in this light, the company's shapeshifting position on native title conveys the impression that their views on Māori were more the product of corporate self-interest than any overarching philosophy on the question of indigenous rights. It was a position that could bend if so required, in this case in response to a realignment of British colonial policy in New Zealand.

Britain's recognition of Māori sovereignty, according to the logic of this new position, was akin to treating a 'savage' nation like 'France or Sicily', an absurdity that shored up the fictitious claim

\footnotetext{
${ }^{83}$ On He Whakaputanga/The Declaration of Independence, see Waitangi Tribunal, He Whakaputanga me te Tiriti The Declaration and the Treaty: The Report on Stage 1 of the Te Paparahi o Te Raki Inquiry (Wellington: Waitangi Tribunal, 2014); Samuel Carpenter, Te Wiremu, Te Puhipi, He Whakaputanga Me Te Tiriti: Henry Williams, James Busby, A Declaration, and the Treaty (Wellington: Waitangi Tribunal, 2009).

${ }^{84}$ [Wakefield], Statement of the Objects of the New Zealand Association, 3.

${ }^{85}$ The scholarship on the Treaty of Waitangi is extensive. The classic account remains Claudia Orange, The Treaty of Waitangi (Wellington: Bridget Williams Books, 1987). See also Ned Fletcher, 'A Praiseworthy Device for Amusing Savages? What the Framers Meant by the English Text of the Treaty of Waitangi' (PhD dis., University of Auckland, 2014). For analysis of te Tiriti from a Māori perspective, see Carwyn Jones, New Treaty, New Tradition: Reconciling New Zealand and Māori Law (Wellington: Victoria University Press, 2016).

${ }^{86} \mathrm{On}$ the law of nations and stadial theory in the islands of New Zealand, see Mark Hickford, Lords of the Land: Indigenous Property Rights and the Jurisprudence of Empire (Oxford: Oxford University Press, 2011), 47-60. See also Pat Moloney, 'Savagery and Civilization: Early Victorian Notions', New Zealand Journal of History 35 (2001): 153-76.

${ }^{87}$ Report from the Select Committee on New Zealand', 38.
} 
that Māori possessed both proprietary rights in land and sovereignty, dominium and imperium. ${ }^{88}$ When questioned on the former, Wakefield pointedly remarked that Māori 'cultivated a piece [of land] for a little while, and then cultivated another piece' ${ }^{89}$ His observation, of course, amounted to more than a claim about the state of Māori agriculture, serving to underline a more fundamental point about the relative classification of Mãori in the stadial model of development.

Stadial theory in this way placed Māori in European time and space: time in the sense that they were assessed according to Western models of historical development, and space in the sense that they were assessed with respect to the lands to which they could legitimately claim rights. ${ }^{90}$ The perception that Māori merely roamed from one piece of land to another, an incorrect observation as it turns out, was thus used to fortify arguments that Māori were incapable of formulating 'abstract' ideas such as sovereignty, a position that Wakefield reinforced by invoking American jurisprudence. ${ }^{91}$ On returning to the select committee for a second day of questioning, he arrived armed with a copy of Henry Wheaton's eighth volume of decisions passed by the United States Supreme Court. When Lord Elliot, the chairman, asked whether Wakefield would like to clarify any of the previous day's evidence, he swiftly replied that his views were supported by the principles found in Johnson v. M'Intosh (1823). ${ }^{92}$

For Wakefield, as for other supporters of the New Zealand Company, Johnson contained a 'very full statement on the subject of the exclusive right of the supreme authority to waste lands of a country inhabited by savage people'. Tailoring his argument to his purposes in the Pacific, Wakefield built on this insight to claim that the New Zealand Company was justified under the law of nations in acquiring land from Māori because the British Crown had legitimately held sovereignty over New Zealand since Cook's discovery in $1769 .{ }^{93}$ Yet, in returning to the 1760 s and Cook's South Sea voyages, Wakefield was also unwittingly returning to the high-water mark of stadial history, a tradition that he had in fact misinterpreted in the first place. In citing Johnson, moreover, he was also returning to North America, that ultimate source of validation and authority for the colonial reformers, the locus of their imperial fantasies.

\section{Conclusion}

Company colonization in South Australia and New Zealand has a global history - a history that links the Atlantic and the antipodes, Māori and metropolitan capital, country and the City of London. It is a history suspended between empire and global capitalism, between London and the far-flung corners of the world. And it is a history that traverses continents as well as centuries. Placed in this broader geographical and temporal context, the colonial reform movement appears more familiar than novel, more the reinvention of tradition than the harbinger of a new mode of colonization. Indeed, as this article has demonstrated, the colonial reformer's very sense of selfunderstanding was paradoxically woven into a long tradition of chartered colonial enterprise that can be traced back to seventeenth-century North America, an insight that refutes the long-held

\footnotetext{
${ }^{88}$ Ibid., 44.

${ }^{89}$ Ibid., 42, 44.

${ }^{90}$ On this theme generally, see J. G. A. Pocock, 'The Treaty Between Histories', in Histories, Power and Loss: Uses of the Past - A New Zealand Commentary, ed. Andrew Sharp and Paul McHugh (Wellington: Bridget Williams Books, 2001), 75-96; J. G. A. Pocock, 'Law, Sovereignty and History in a Divided Culture: The Case of New Zealand and the Treaty of Waitangi', in J. G. A. Pocock, The Discovery of Islands: Essays in British History (Cambridge: Cambridge University Press, 2005), 226-55.

${ }^{91}$ 'Report from the Select Committee on New Zealand', 40-2. On American jurisprudence in the context of colonial New Zealand, see Mark Hickford, “'Decidedly the Most Interesting Savages on the Globe”: An Approach to the Intellectual History of Māori Property Rights, 1837-1853', History of Political Thought 27 (2006), 148-53.

${ }^{92}$ 'Report from the Select Committee on New Zealand', 53.

${ }^{93} \mathrm{Ibid}$. On Chief Justice Marshall and Johnson v. M'Intosh, see Blake A. Watson, Buying America from the Indians: Johnson v McIntosh and the History of Native Land Rights (Norman, OK: University of Oklahoma Press, 2012); Eric Kades, 'History and Interpretation of the Great Case of Johnson v M'Intosh', Law and History Review 19 (2001): 67-116.
} 
assumption that systematic colonization represented an original intervention in the political economy of empire. From the Atlantic seaboard in the early seventeenth century to the foreshore and seabed of New Zealand in the wake of the Treaty of Waitangi, British company colonization long shaped the modern world.

Yet, as the article has shown, historians of South Australia and New Zealand have tended to analyse colonial reform in more narrowly defined regional and national frameworks, and as a result the connection between companies and colonization in the antipodes has seldom been interrogated. The article has challenged such histories by foregrounding companies, an analytical move that situates the colonial reform movement in global context. In thus connecting antipodean company colonization to its Atlantic predecessor, a discursive and historical link that the actors self-consciously cultivated, I have shown how and why history and historical narrative influenced practical plans to colonize South Australia and New Zealand.

This more expansive temporal lens also sharpens our understanding of how the colonial reformers rationalized indigenous dispossession. Though unquestionably a tradition that performed powerful symbolic functions, the history of the Virginia Company and the Massachusetts Bay Company also had a legal dimension, and one that the colonial reformers turned to in order to make juridical claims about their rights in relation to indigenous peoples. Accordingly, this article has demonstrated how the colonial reformers drew on English colonial history to justify the appropriation of Aboriginal Australian and Māori tribal land.

A commitment to taking companies seriously also invites us to consider how the histories of South Australia and New Zealand intersect with the global history of capitalism, a burgeoning literature that has not yet received sustained consideration by historians of settler colonialism. Who were the directors and shareholders of these companies? What were their social and cultural backgrounds, their institutional links to Westminster and the City of London? How did the South Australian Association or the New Zealand Company operate on a day-to-day basis? Placed in this context, the colonial reform movement assumes a radically different character, one where boardrooms and taverns, banks and country retreats, loom as large as the inner workings of the Colonial Office, long the focus of imperial historiography.

British company colonization forever changed the Pacific and Indian ocean new worlds, but it is important to remember that it was imaginatively conceived on Atlantic shorelines. The Samoan-New Zealand historian Damon Salesa has rightly noted that the antipodes are 'on not just opposite, but also apposite, footings' ${ }^{94}$ In recovering how North America informed practical plans to colonize South Australia and New Zealand, this article has prompted a reconsideration of the connections binding Atlantic and antipodean company colonization, connections that, once interrogated, reveal the little-known story of how chartered colonial enterprise propelled the settler revolution.

Matthew Birchall is a doctoral candidate in history at the University of Cambridge. He is completing a dissertation on company colonization and the settler revolution.

\footnotetext{
${ }^{94}$ Damon Ieremia Salesa, 'Afterword: Opposite Footers', in Atlantic World in the Antipodes, ed. Fullagar, 297.
} 